Alexander, E. Calvin Jr., Scott C. Alexander, James J. Piegat, Kelton D. Barr and Brad Nordberg (2005) Dye Tracing Sewage Lagoon Discharge in a Sandstone Karst, Askov, Minnesota. In: Sinkholes and the Engineering and Environmental Impacts of Karst. Proceedings of the $10^{\text {th }}$ Multidisciplinary Conference.Sept. 24-28, 2005. San Antonio, Texas. ASCE Geotechnical Special Publication No. 144, pages 449-458.

\title{
Dye Tracing Sewage Lagoon Discharge in a Sandstone Karst, Askov, Minnesota
}

\author{
E. Calvin Alexander, Jr. ${ }^{1}$, Scott C. Alexander ${ }^{1}$, James J. Piegat ${ }^{2}$, Kelton D. Barr ${ }^{2}$ and Brad Nordberg ${ }^{3}$
}

\begin{abstract}
An investigation of the sandstone karst at Askov, Pine County, Minnesota was conducted utilizing fluorescent dye tracing techniques. Connections were documented between the effluent from WWTF lagoons discharged into a sinking stream and local residential water supply wells southwest of the stream sink, over kilometer-scale distances. The apparent velocity of dye from the steam sink to the residential well was $57 \mathrm{~m} /$ day, much faster than would be expected for porous-media flow in a sandstone but slower than expected for well-developed conduit karst in carbonate rock.

The traces also document stage-dependent, divergent flow to the northeast and west from recharge to a sinkhole adjacent to the lagoons. A well-developed conduit system extends a few hundred meters under the northern portion of the lagoons with flow velocities greater than $128 \mathrm{~m} /$ day to the northeast. A slower flow system extends for at least a kilometer to the west and northwest with a range of apparent flow velocities that average about $9 \mathrm{~m} /$ day. The slower flow system reached a broad "fan" of residential wells to the west but was not detected in other wells in the same direction.
\end{abstract}

\section{Introduction}

Despite voluminous literature documenting karst phenomena in sandstones and quartzites (see Wray (1997) and Shade (2002) for reviews), many geoscientists and geoengineers consider karst phenomena to be restricted to carbonates and other rare types of soluble rocks. That mistaken belief caused the senior author to dismiss for two decades anecdotal reports of sinkholes formed in Minnesota's Hinckley Sandstone.

Three of 23 municipal waste water treatment facility (WWTF) lagoons constructed 30 to 40 years ago in Minnesota's carbonate karst have failed by catastrophic sinkhole development (Alexander and Book, 1984; Jannik et al., 1992; Alexander et al., 1993). When Shade (2002) documented active karst developed on the Hinckley Sandstone in central Pine County, Minnesota (Figure 1), her work alerted resource managers to ground water concerns in this previously unrecognised karst. Askov has placed a moratorium on new sewer hook-ups for several years because of limited capacity in their 40 year-old WWTF lagoons. Effluent is periodically discharged from the lagoons sinks and enters ground water through the "Big Sink Hole" one kilometer down stream. Several sinkholes are located immediately adjacent to the lagoons. Recognition of the potential lagoon collapse and continual effluent discharge problems limited the options for upgrading Askov's WWTF - but also greatly increased the visibility of and priority for state aid in Askov's efforts to resolve these problems.

\footnotetext{
${ }^{1}$ Geology \& Geophysics Department, University of Minnesota, 310 Pillsbury Dr. SE, Minneapolis, MN 55455; PH (612) 624-3517, FAX (612) 625-3819; email: alexa001@umn.edu

2 present address Emmons \& Olivier Resources, Inc., 651 Hale Ave., N., Oakdale, MN 55128; PH (651) 203-6041; FAX (651) 770-2552; email: kbarr@eorinc.com

${ }^{3}$ Minnesota Pollution Control Agency (MPCA), 520 Lafayette Rd., St. Paul, MN 55155; PH (651) 296-

7298; FAX (651) 297-8683; email: bradley.nordberg@pca.state.mn.us
} 
Alexander, E. Calvin Jr., Scott C. Alexander, James J. Piegat, Kelton D. Barr and Brad Nordberg (2005) Dye Tracing Sewage Lagoon Discharge in a Sandstone Karst, Askov, Minnesota. In: Sinkholes and the Engineering and

Environmental Impacts of Karst. Proceedings of the $10^{\text {th }}$ Multidisciplinary Conference.Sept. 24-28, 2005. San Antonio, Texas. ASCE Geotechnical Special Publication No. 144, pages 449-458.

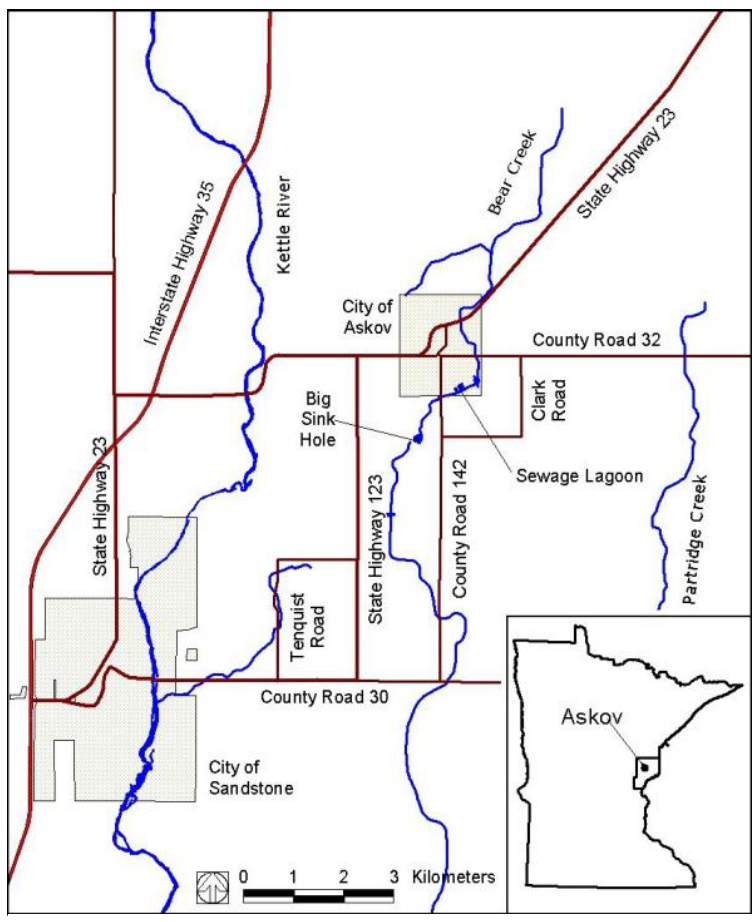

Figure 1. Location and detail of study area.

As part of a receptor survey near the Askov WWTF, two fluorescent dye traces were initiated on 23 April 2004. Rhodamine WT was added to the routine discharge of lagoon effluent to the adjacent sinking stream and fluorescein was injected into a sinkhole immediately west of the lagoon. The results of those dye traces and other investigations were detailed in $\mathrm{E}^{\mathrm{x}}$ ponent (2004) and the dye trace work is summarized here.

\section{Geologic and Hydrogeologic Setting}

Geology: The bedrock geology of the Askov area consists of Mesoproterozoic volcanic and sedimentary rocks deposited in the Midcontinent Rift System (Boerboom, 2001; Boerboom et al., 2002;) formed 1,109-1,087 million years ago (Ojakangas et al., 2001). Basalts were deposited during the extensional phase of rift formation. After extension and volcanism ceased, continued subsidence provided a basin for the deposition of an unnamed sandstone, the Fond du Lac Formation, and the Hinckley Sandstone (listed in order from oldest to youngest). Compression during or after deposition cut these sedimentary units with high-angle reverse faults. The reverse faults, including the Hinckley, Douglas, and Pine faults, generally follow the structural trend of the rift. The reverse faults trend northeast-southwest in the Askov area. The Hinckley Fault is located about three km southeast of Askov; the Douglas and Pine faults are located farther to the southeast.

The area has been glaciated many times during the Pleistocene. The Grantsburg and Superior ice lobes deposited the glacial landforms and materials present at or near the present land surface during the latest glaciation, 25,000 to 10,000 years ago (Patterson and Knaeble, 2002). Glacial materials in the Askov area consist of sandy glacial sediments, sandy end moraine sediments, and stream sediments deposited by the Superior lobe. Glacial deposits are less than $15 \mathrm{~m}$ thick over much of the area around Askov. Greater sediment thickness of 15-30 m are found south of Askov along the north side of the Hinckley Fault. A buried bedrock valley filled with up to $60 \mathrm{~m}$ of glacial material is located about five $\mathrm{km}$ southwest.

Karst: Geographers originally defined karst as a "terrain with distinctive characteristics of relief and drainage arising primarily from a higher degree of rock solubility in natural waters than is found elsewhere" (Jennings, 1971). A karst terrain is characterized by closed depressions, sinkholes, swallow holes, subterranean drainage along discrete channels opened by solution, springs, and caves. Jennings (1983) later expanded the definition of karst to emphasize the importance of subsurface aquifers in a karst terrain. Karst aquifers are defined as aquifers that have flow in conduits, "a specific type of fluid circulation capable of self-development and self-organizations" (Klimochouk and Ford, 2000).

Karst occurs most often in limestones and dolomites because those rocks are common and relatively soluble in water. A common igneous mineral resistant to weathering, quartz is about $1 / 10$ as soluble as carbonates in pure water. Hence, karst landscapes may also develop in sandstone, given sufficient time or water (Wray, 1997). Karst features in the Askov area were mapped by (Troung, 2001), and joint efforts of the University of Minnesota and Pine County Soil and Water Conservation District (Shade, 2002).

Shade et al (2001) mapped more than 300 karst features in Pine County including sinkholes, streamsinks and springs. The sinkholes consist of glacial materials piped and collapsed into solutionally- 
Alexander, E. Calvin Jr., Scott C. Alexander, James J. Piegat, Kelton D. Barr and Brad Nordberg (2005) Dye Tracing Sewage Lagoon Discharge in a Sandstone Karst, Askov, Minnesota. In: Sinkholes and the Engineering and

Environmental Impacts of Karst. Proceedings of the $10^{\text {th }}$ Multidisciplinary Conference.Sept. 24-28, 2005. San Antonio, Texas. ASCE Geotechnical Special Publication No. 144, pages 449-458.

enlarged joints and cavities developed in the Hinckley Sandstone. The mapped sinkholes are located in an area about $29 \mathrm{~km}$ by $8 \mathrm{~km}$ on the northwest side of the Hinckley Fault. The Hinckley Fault appears to be a fundamental boundary that controls the occurrence of sinkholes. Sinkholes were sought but not found southeast of the fault. The sinkhole array may extend further in other directions. Northwest of the Hinckley Fault, on the down-thrown side, the Hinckley Sandstone is as much as 300 to $450 \mathrm{~m}$ thick; southeast of the fault, and is much thinner on the up-thrown side, with only the basal portion remaining. Apparently, the basal Hinckley Sandstone contains quantities of other minerals sufficient to prevent the formation of solution channels and cavities or to clog any that develop.

Hydrogeology: The Hinckley Sandstone is the sole aquifer used by both the City of Askov and nearby residential wells. Secondary porosity is important factor in the relatively high hydraulic conductivity of the Hinckley in the Askov area (Berg, 2004a). For example, the City's municipal wells were designed to intercept as many near-surface fractures as possible to provide a favorable yield (Jim deLambert, personal communication). Based on data considered sparse for the purpose of this study, ground water generally flows to the west, southwest, and south in the Askov area (Berg, 2004a). The principal ground water sink is the south-draining Kettle River which comes as close as four km west of Askov.

Ground water samples from the Askov area have high (three samples) to moderate (one sample) levels of tritium, indicating that rapid recharge occurs in the Hinckley Sandstone. This is consistent with the thin, sandy loam surficial material and a chloride/bromide ratio (one sample) sufficiently high to be attributable to human activities. Consequently, the single aquifer in Askov area is generally mapped as being very highly sensitive to ground water pollution (Berg, 2004b). This rating means that contaminants released at the land surface may reach the water table in one month or less.

\section{Methods}

One dye test injected Rhodamine WT into sewage lagoon effluent to determine the fate of that effluent under normal conditions. A second dye test injected fluorescein into a sinkhole immediately adjacent to the sewage lagoons to assess the fate of lagoon effluent discharged under high-flow conditions and the fate of effluent should the lagoon fail by sinkhole collapse. Both dyes were injected on 23 April 2005.

Dye Trace Monitoring Network: Movement of the dyes was monitored by a network of charcoal collectors (bugs) placed at selected surface water points and in the water systems of selected homes. Bugs were replaced weekly during the months of April, May, and June; and every two weeks during the months of July and August, 2005.

During the week of 14 April 2004, bugs were installed in three springs along the Kettle River about $4 \mathrm{~km}$ west of Askov and three bugs were installed in creeks where they crossed Pine County Road 30 about $6.5 \mathrm{~km}$ south of Askov. These six bugs were placed at points where ground water in the Askov area might ultimately discharge to surface water. Four additional bugs were placed along Bear Creek, two upstream from the injection points, at the crossings of Minnesota State Road 23 and Pine County Road 32 as controls and two downstream of the lagoons, one at the crossing of Bear Creek at Pine County Road 142 and one just upstream of the Big Sink Hole. 19 bugs were installed in individual water systems, including the Askov municipal system. These locations were chosen by identifying landowners who lived within 1.6 $\mathrm{km}$ of either the sewage lagoons or the Big Sink Hole. The first round of 29 bugs was changed on 21-22 April and analysed to provide background information.

On 21 April 2004, bugs were installed in each of four new monitoring wells drilled in the lagoon berms and in two additional homes at the request of the landowners. On 25 May 2004, six additional bugs were installed in systems near well W02 after dye was detected in that well. On 1 June 2004, three additional bugs were installed in systems considered downstream from well W02. On 15 July, one bug was installed in another system also considered downstream from well W02. The last set of bugs was pulled on 27 August 2004, which ended the monitoring for the dyes. 
Alexander, E. Calvin Jr., Scott C. Alexander, James J. Piegat, Kelton D. Barr and Brad Nordberg (2005) Dye Tracing Sewage Lagoon Discharge in a Sandstone Karst, Askov, Minnesota. In: Sinkholes and the Engineering and

Environmental Impacts of Karst. Proceedings of the $10^{\text {th }}$ Multidisciplinary Conference.Sept. 24-28, 2005. San Antonio, Texas. ASCE Geotechnical Special Publication No. 144, pages 449-458.

Lagoon Discharge: Under normal conditions, the Askov lagoons are discharged to Bear Creek twice per year. On 23 April 2004, about two liters of $20 \mathrm{wt} \%$ Rhodamine WT solution (441.5 g of dye) was poured into a scheduled discharge of lagoon effluent. The injection point was the outlet structure of lagoon cell \#2 (the smaller cell). Approximately 3.8 million liters of effluent were discharged to Bear Creek over several days. The dye was visibly traced as it flowed down Bear Creek to the Big Sink Hole. Under conditions prevailing at the time of dye injection, all of the flow of Bear Creek, and hence all of the lagoon discharge, sank to the ground-water system at the Big Sink Hole.

Lagoon Sinkholes: On 23 April 2004, about one liter of $35 \mathrm{wt} \%$ fluorescein solution (412.8 g of dye) was injected into sinkhole MN58:D0055 (D55) located about $40 \mathrm{~m}$ to the west of the lagoon. Sinkhole D55 is flooded by water from Bear Creek during high flows. The dye was washed into the sinkhole with 11,000 liters of water provided by the City fire department. The first 5,500 liters were poured into D55 at 57 liters/min, which was the rate that the sinkhole drained water. The remaining 5,500 liters were then flooded into the sinkhole and allowed to infiltrate.

Charcoal Detectors (bugs): Charcoal detectors were constructed by enclosing $4 \mathrm{~g}$ of activated carbon (Barnebey \& Sutcliffe Type AC coconut shell carbon 6x12 mesh) in a $5 \mathrm{~cm}$ x $20 \mathrm{~cm}$ section of milk sock filter tube stapled on both ends. A plastic tag was attached to the bug with a short piece of wire. This wire also served to attach the bug to a weight, which keeps the bug submerged, and to a fixed object, which prevents the bug from washing away. Dyes were recovered in the laboratory by placing about $1 \mathrm{~g}$ (dry weight) activated carbon into a $16 \times 100 \mathrm{~mm}$ disposable test tube and adding $8 \mathrm{ml}$ of eluent. The remaining carbon was stored in a freezer for later re-analysis if required. The eluent used was a solution of $70 \% 2$ propanol (CAS 67-63-0) and $30 \%$ de-ionized water saturated with $\mathrm{NaOH}$ (CAS 1310-73-2) ( 10 g $\mathrm{NaOH} /$ liter of eluent) mixed in a separatory funnel and the dense phase, containing excess water and $\mathrm{NaOH}$, was discarded. The lighter phase was a $\mathrm{NaOH}$ saturated solution of water and 2-propanol. The resulting eluent was scanned as a blank before proceeding with sample elution. After a one-hour extraction period the resulting elutant is analysed by pipetting $4 \mathrm{ml}$ of elutant from the test tube into a $13 \times 100 \mathrm{~mm}$ borosilicate glass vial with a screw cap.

Dye Analyses: The concentration of the fluorescent dyes Rhodamine WT (CAS 37299-86-8) and fluorescein (CAS 518-47-8) can be quantitatively measured with a spectrofluorophotometer. These analyses used a Shimadzu RF-5,000 scanning spectrofluorophotometer. The dyes were measured simultaneously using a synchronous scan mode wavelength separation $(\Delta \lambda)$ of $15 \mathrm{~nm}$. Excitation wavelengths were scanned from $385 \mathrm{~nm}$ to $635 \mathrm{~nm}$; emission wavelengths were scanned from $400 \mathrm{~nm}$ to $650 \mathrm{~nm}$ at high sensitivity. Bandwidths for emission and excitation were set at $5 \mathrm{~nm}$ and the scan rate is set at $30 \mathrm{~nm} / \mathrm{sec}$. This $\Delta \lambda$ is optimized for eosin and Rhodamine WT which have the poorest detection limits, but have a maximum fluorescence response at $\Delta \lambda=15 \mathrm{~nm}$. Fluorescein response is slightly degraded but still has the lowest detection limits by an order of magnitude.

The resulting fluorescence spectra were saved as text files. The Peakfit ${ }^{\mathrm{TM}}$ program, version 4.0, by Jandel Scientific, Inc., was used to separate the various components of the spectra using the techniques described elsewhere in this volume by Alexander (2005). The results of these traces are discussed below.

\section{Results}

Lagoon Discharge: Injection of Rhodamine WT to the normal discharge of lagoon cell \#2 on 23 April 2004 was designed to: 1) compare conduit flow with porous-media flow in the ground-water system; 2) determine the extent ground-water contamination by waste water at normal stream flow; and 3) identify receptors that may be hydraulically connected to the lagoons or discharge stream.

Rhodamine WT dye was visibly traced as it travelled approximately $1 \mathrm{~km}$ down Bear Creek from the lagoon cell \#2 to the Big Sink Hole during a three-hour period. Dye concentration dropped below visibility as the flow mixed with the water in the Big Sink Hole. Rhodamine WT was detected in the two bugs in Bear Creek between the injection point and the Big Sink Hole. Dye was highest in bugs collected four days after injection and the dye concentration declined in subsequent weeks. 
Alexander, E. Calvin Jr., Scott C. Alexander, James J. Piegat, Kelton D. Barr and Brad Nordberg (2005) Dye Tracing Sewage Lagoon Discharge in a Sandstone Karst, Askov, Minnesota. In: Sinkholes and the Engineering and

Environmental Impacts of Karst. Proceedings of the $10^{\text {th }}$ Multidisciplinary Conference.Sept. 24-28, 2005. San Antonio, Texas. ASCE Geotechnical Special Publication No. 144, pages 449-458.

Rhodamine WT was detected in well W02 25 days after the test began as shown in Figure 2. Dye concentration in W02 rose during the next three weeks and then generally declined through the end of sampling. W02 is located $1.5 \mathrm{~km}$ southwest of the Big Sink Hole. In response to this detection, ten new bugs were installed in the area surrounding W02. Of those ten bugs, Rhodamine WT was eventually confirmed in only one, W26 located $0.5 \mathrm{~km}$ south of W02. Rhodamine WT in W26 was first detected 60 days after the test began; the concentration peaked one week later, and declined below the detection limit three weeks after the first detection (Figure 2).

There are suggestions of Rhodamine WT in two other wells (W27 and W28) near W02 and W26, but presence of the dye could not be confirmed. Rhodamine WT was not detected in any other wells or in any surface-water monitoring sites.

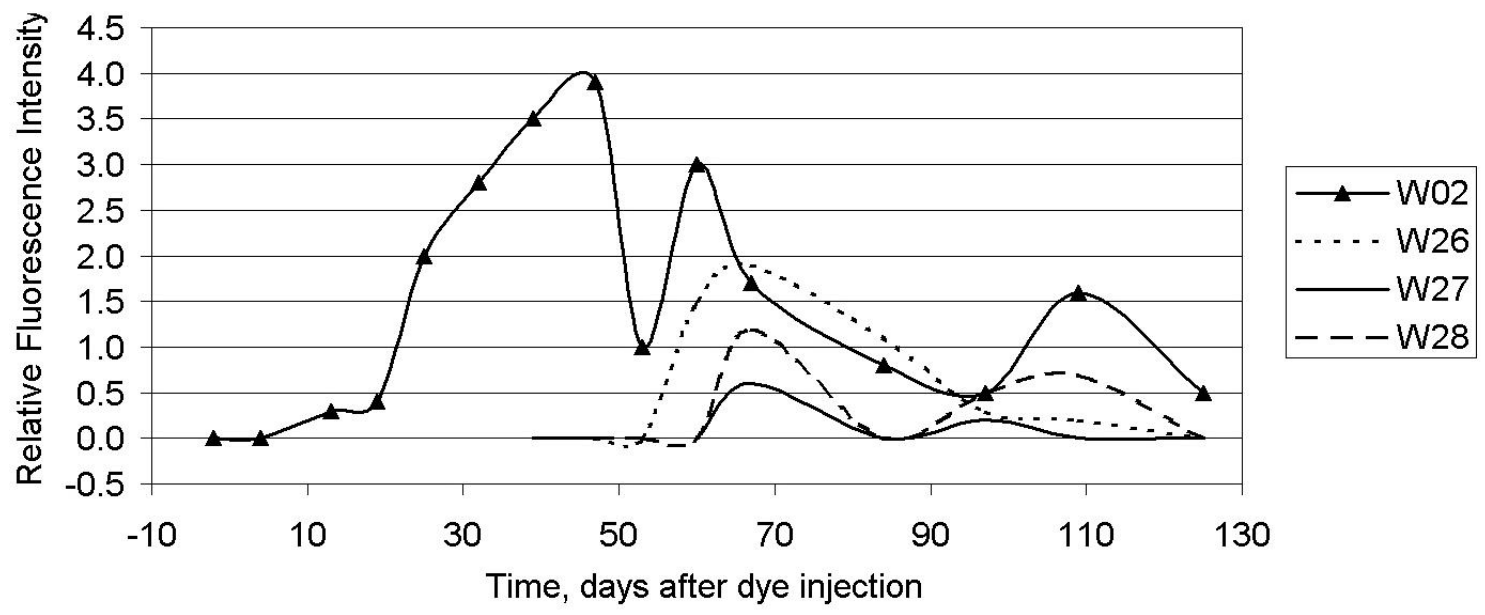

Figure 2. Rhodamine WT dye detection in residential wells W02, W26, W27 and W28.

The minimum apparent ground-water flow velocities for the Rhodamine WT trace from the Big Sinkhole to W02 was calculated from the straight line distance and the travel time of the leading edge of the dye to W02. The velocity, $57 \mathrm{~m} /$ day, is much too fast for porous-media flow, but is slower than might be expected in a mature limestone karst. There are several possible explanations, including: 1) less solution enlargement of the sandstone fractures; 2) W02 is not located directly along the major fracture and some porous-media flow has occurred in response to pumping by that well; 3) the hydraulic gradient is too low to allow higher velocities; 4) the fracture is not continuous but is a series of en echelon fractures, requiring porous-media flow from one to the next; 5) the fractures have been partially clogged by glacial sediments. The delayed appearance of Rhodamine WT in W26 may suggest that there was some porousmedia flow to that well.

A line drawn through W02 and parallel to the Hinckley Fault (2.3 km to the southeast) passes very close to both the Big Sink Hole and other sinkholes immediately to the west of the sewage lagoon. The conclusion is that Rhodamine WT, and the sewage lagoon effluent into which it was injected, entered the Big Sink Hole and flowed to the southwest along a major, solution-enlarged fracture that is parallel to the Hinckley Fault.

Lagoon Sinkholes: Under normal conditions, the Askov lagoon contains millions of liters of partially treated sewage. Collapse of the lagoon into a sinkhole would release that sewage into the groundwater system. Under conditions of high flow in Bear Creek, the creek overflows its bank and drains into sinkholes immediately west of lagoon cell \#2. Some portion of the effluent released during high flow may enter those sinkholes and reach the ground-water system.

Injection of fluorescein dye into a sinkhole located 40 m west of lagoon cell \#2 on 23 April 2004 was designed to: 1) compare conduit flow with porous media flow in the ground-water system; 2) 
Alexander, E. Calvin Jr., Scott C. Alexander, James J. Piegat, Kelton D. Barr and Brad Nordberg (2005) Dye Tracing Sewage Lagoon Discharge in a Sandstone Karst, Askov, Minnesota. In: Sinkholes and the Engineering and

Environmental Impacts of Karst. Proceedings of the $10^{\text {th }}$ Multidisciplinary Conference.Sept. 24-28, 2005. San Antonio, Texas. ASCE Geotechnical Special Publication No. 144, pages 449-458.

determine the extent of adverse effects of waste water on the ground-water system at high stream flow; 3) identify receptors that may be hydraulically connected to the lagoon or discharge stream; and 4) provide data for a failure-probability analysis on the current lagoon, or an assessment of the geologic hazards associated with the current lagoon;

Fluorescein appeared in the first bugs collected after injection from two of the four monitoring wells installed around the lagoon (W21 and W22). Fluorescein concentration in W21 peaked 19 days after injection, declined by one-third the following week, and then remained relatively constant through August. In W22, located on the north side of the lagoon, concentration peaked 47 days after injection, declined to about $20 \%$ of the maximum value by the following week, and remained relatively constant through August. Fluorescein concentration in W23, located to farthest from the injection point, was at a modest level in a bug collected four days after injection, peaked in the bug collected the next week, and then dropped below the detection limit in the bug collected the following week where it has remained. Fluorescein was found in W20, located on the south side of the lagoon, 19 days after dye injection, but could not be confirmed. The initial movement of the fluorescein was to the east-northeast under the northern part of the lagoon, perhaps driven by a recharge mound produced by the water used to flood the sinkhole. A logical sink for this flow would be along conduits to a swallow hole of Bear Creek upstream of the lagoon. This interpretation is consistent with the lower static water level in MW23.

The travel time to the three northern monitoring wells was less than four days. These dye detections document the presence of rapid flow paths to the east-northeast under the lagoon itself. Only lower limits can be placed on the flow velocity of shallow groundwater under the lagoons. The highest

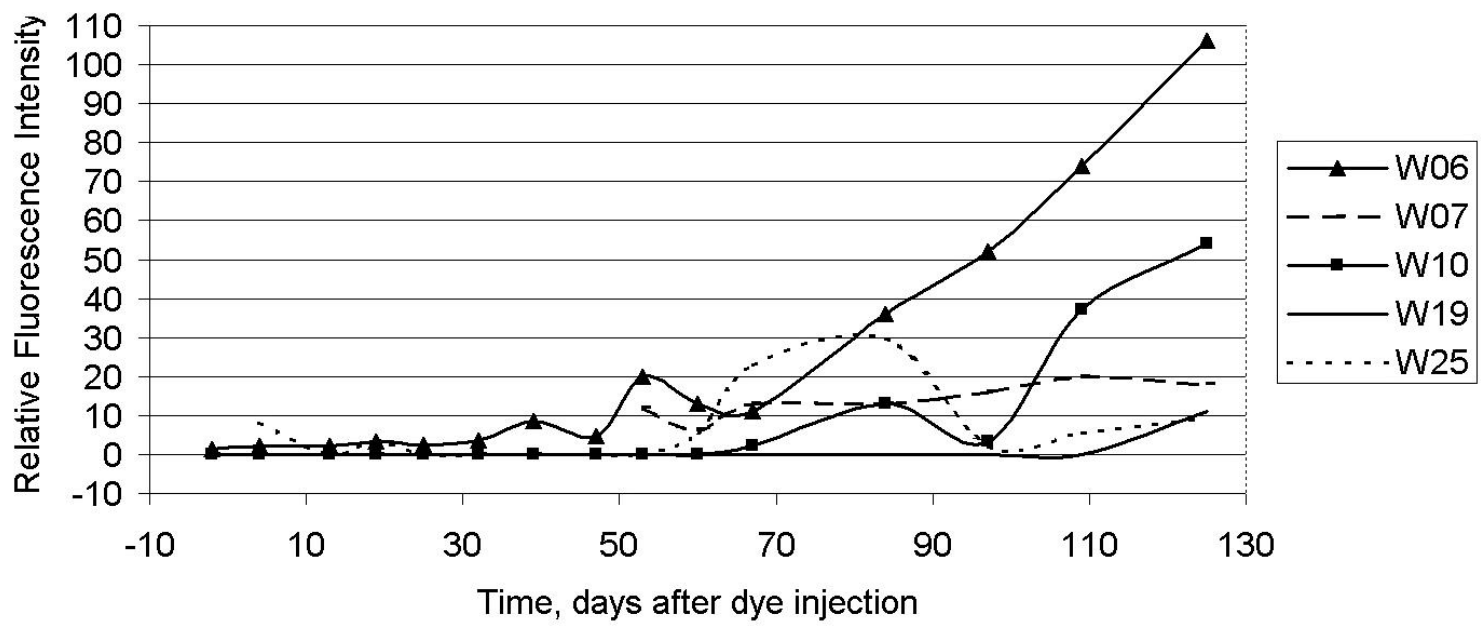

Figure 3. Fluorescein dye detection in residential wells W06, W07, W10, W19 and W25.

lower limit, $>128 \mathrm{~m} / \mathrm{day}$, is from the fluorescein detected in MW23 by 27 April.

Fluorescein was detected in five residential wells, W06, W07, W10, W19, and W25 (Figure 3). All of these wells are west of D55 and document a flow direction directly opposite to the flow indicated by the monitoring wells. This pattern is consistent with flow driven by a recharge mound created during dye injection. Fluorescein concentration steadily increased with time in wells W06, W07, W10 and W19. In well W25, fluorescein was suggested by two bugs early in the study (bugs collected four and 19 days after injection, but not in the bug collected after 13 days), and was detected by the bug collected 60 days after dye injection. Concentration then rose during the period from 60 to 84 days after injection, decreased by an order of magnitude during the subsequent week, and steadily rose to the end of sampling.

The average flow velocity to the first four residential wells with confirmed fluorescein detections is $9 \mathrm{~m} /$ day. This velocity is lower than that yielded by the Big Sink Hole to W02 trace and may indicate a 
Alexander, E. Calvin Jr., Scott C. Alexander, James J. Piegat, Kelton D. Barr and Brad Nordberg (2005) Dye Tracing Sewage Lagoon Discharge in a Sandstone Karst, Askov, Minnesota. In: Sinkholes and the Engineering and Environmental Impacts of Karst. Proceedings of the $10^{\text {th }}$ Multidisciplinary Conference.Sept. 24-28, 2005. San Antonio, Texas. ASCE Geotechnical Special Publication No. 144, pages 449-458.

mixture of rapid flow through conduits and a short but much slower flow through a porous media from the conduit to the individual well. It is unlikely that any individual well is drilled directly into a solution enlarged fracture conduit. The short time between dye injection and the appearance of fluorescein in wells

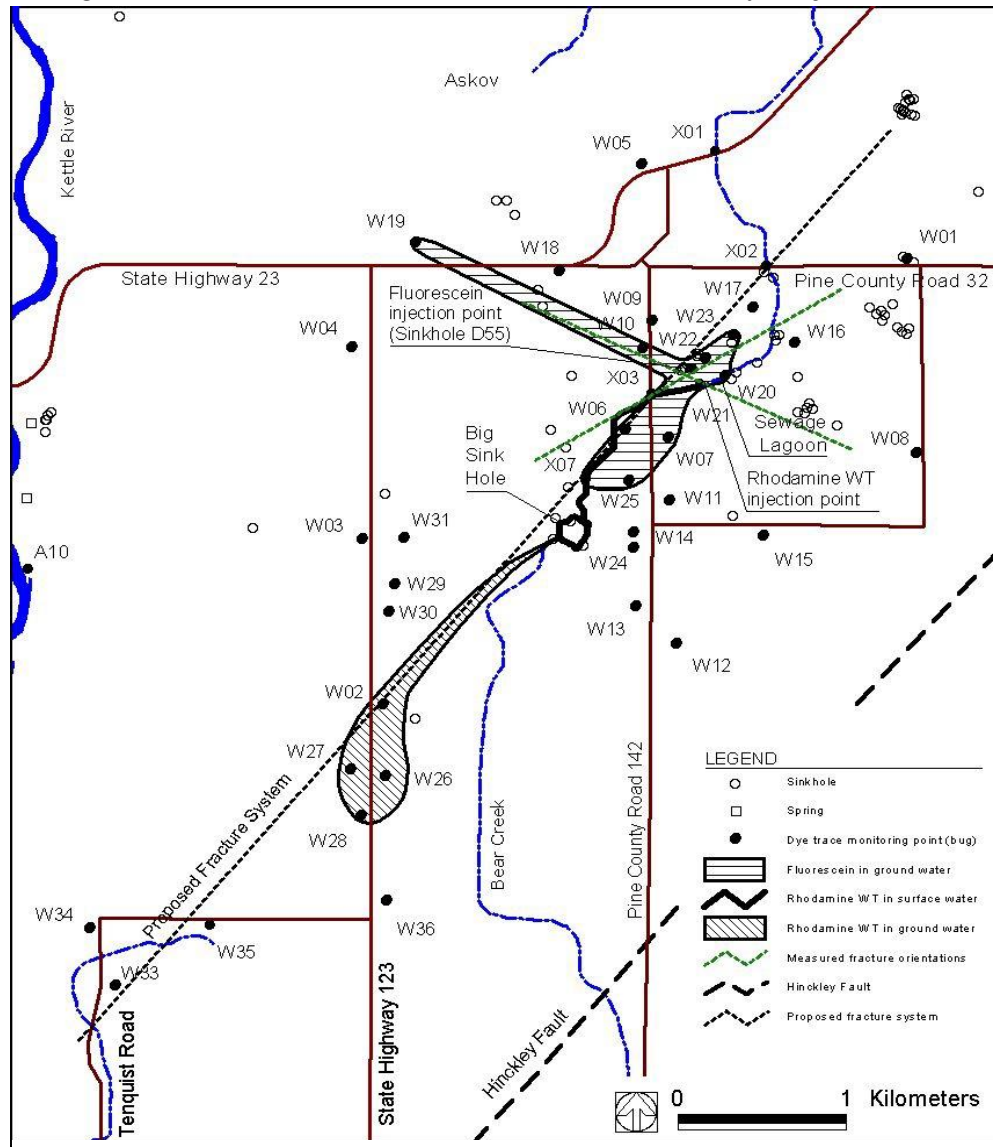

Figure 4. Relationship of karst features, Rhodamine WT detections, fluorescein detections and the structural trend of the Hinckley Fault.
W06, W19, W25, and perhaps W07 and W10 indicates that fracture flow is a significant, if not the dominant mode of ground-water flow in the vicinity of the lagoons (Figure 4).

Well W06 is located very close to a line drawn parallel to the Hinckley Fault and through the sinkhole in which the fluorescein was injected. This is the same line that passes near the Big Sink Hole and well W02 in which Rhodamine WT was detected. It is possible that flow along a major fracture along this line is relatively fast and that the delay between time of dye injection and appearance in various wells is related to a slower, porousmedia flow perpendicular to the major fracture. However, fluorescein was not detected in well W02. This suggests that the proposed fracture system located along a line from W02 to the lagoon is not uniformly transmissive. It is more likely that restrictions to flow occur in this system, probably between W06 and the Big Sink Hole.

The detection of fluorescein in well W19 in the last week of the study is problematic. Because the study ended at that time, it was not be confirmed by a second detection. It is possible that the dye has another source. If the dye did come from the test, then it must have moved through a solution-enlarged conduit. This conclusion is based on: 1) the rapid rate of movement (33 m/day); 2) the lack of dye in W18 that is half the distance to the injection point, and slightly off the line between the injection point and W19; and 3) the correlation in the direction of a line from the injection point to W19 and one of the principle fracture directions measured in the Hinckley Sandstone.

Fluorescein did not appeared in any of the bugs located in springs (A09, A10, A11), stream crossings of Pine County Road 30 (X04, X05, X06), or Bear Creek upstream from the lagoon (X01, X02).

\section{Summary}

An investigation of the sandstone karst at Askov, Pine County, Minnesota was conducted utilizing fluorescent dye tracing techniques. Connections were documented between the effluent from WWTF 
Alexander, E. Calvin Jr., Scott C. Alexander, James J. Piegat, Kelton D. Barr and Brad Nordberg (2005) Dye Tracing Sewage Lagoon Discharge in a Sandstone Karst, Askov, Minnesota. In: Sinkholes and the Engineering and

Environmental Impacts of Karst. Proceedings of the $10^{\text {th }}$ Multidisciplinary Conference.Sept. 24-28, 2005. San Antonio, Texas. ASCE Geotechnical Special Publication No. 144, pages 449-458.

lagoons discharged into a sinking stream and local residential water supply wells southwest of the stream sink, over kilometer-scale distances. The apparent velocity of dye from the steam sink to the residential well was $57 \mathrm{~m} /$ day, much faster than would be expected for porous-media flow in a sandstone but slower than expected for well-developed conduit karst in carbonate rock. A simple explanation is that both types of flow are involved with rapid flow in solutionally-enlarged conduits in the sandstone followed by shorter, but slower porous-media flow from the conduits to the individual wells.

The traces also document stage-dependent, divergent flow to the northeast and west from recharge to a sinkhole adjacent to the lagoons. A well-developed conduit system extends a few hundred meters under the northern portion of the lagoons with flow velocities greater than $128 \mathrm{~m} /$ day to the northeast. A slower flow system extends for at least a kilometer to the west and northwest with a range of apparent flow velocities that average about $9 \mathrm{~m} /$ day. The slower flow system reached a broad "fan" of residential wells to the west but was not detected in other wells in the same direction. Such a pattern is inconsistent with pure porous-media flow but is a well-documented phenomenon in fractured and conduit aquifers.

\section{Epilogue}

This study quantified the groundwater impact of Askov's 40-year-old municipal WWTF on a karst hydrogeologic system. The low cost option of expanding the current multi-cell lagoon system was precluded. The originally contentious tone of the entire dialog has changed for the better.

Askov's municipal government was initially concerned that the karst hydrogeology would limit their options for a sorely needed upgraded WWTF. While they did not want to impact their own or their neighbors' water supplies the remaining options were more expensive and totally beyond the limited financial resources of Askov. The City of Askov realized that by documenting the ongoing and potential impacts of the existing WWTF their chances of securing significant additional state financial aid significantly improved. Several of the owners had long thought that the WWTF effluent was affecting their wells. These residents felt vindicated and were reassured that the longstanding problems would be addressed. Those owners who had not considered the possibility were initially surprised but were also reassured that the traces were the beginning of a process that would resolve the problem.

MPCA staff are working closely with Askov and with the local political representatives to secure additional state aid. As of May 2005, the current concept is to build new WWTF lagoons a few kilometers south and east of the existing site on the other side of the Hinckley Fault beyond the mapped karst region. All involved are working toward a common resolution of the problem.

\section{Acknowledgments}

We thank the residents in and around Askov whose active participation made this work possible. This effort would not have happened if Hong Truong and Bev Shade had not found and documented this sandstone karst. Askov city staff, particularly Arla Budd and Colin Voss, provided important support. Paul Carter of West Central Environmental Consultants professionally handled much of the logistics. Rodney Ikola's geophysical investigations provided key insights. This work was supported by the Minnesota Pollution Control Agency. Sandeep Burman and Ron Swenson of the MPCA staff provided much critical leadership and support.

\section{References}

Alexander, E.C., Jr. and Book, P.R. (1984) Altura Minnesota lagoon collapses. in: Beck, B. (editor) Sinkholes: Their Geology, Engineering and Environmental Impact, A.A. Balkema, Rotterdam, The Netherlands, p. 311-318.

Alexander, E.C., Jr., Broberg, Jeffery S., Kehren, Andrew R. Graziai, Marco M. and Turri, Wendy L. (1993) Bellechester Minnesota Lagoon Collapses. Environ. Geol., v. 22, n. 4, p. 353-361.

Alexander, Scott C. (2005) Spectral deconvolution of natural organics and man-made fluorescent dyes. This volume. 
Alexander, E. Calvin Jr., Scott C. Alexander, James J. Piegat, Kelton D. Barr and Brad Nordberg (2005) Dye Tracing Sewage Lagoon Discharge in a Sandstone Karst, Askov, Minnesota. In: Sinkholes and the Engineering and

Environmental Impacts of Karst. Proceedings of the $10^{\text {th }}$ Multidisciplinary Conference.Sept. 24-28, 2005. San Antonio, Texas. ASCE Geotechnical Special Publication No. 144, pages 449-458.

Berg, J.A. (2004a) Hydrogeology of the unconsolidated and bedrock aquifers: Minnesota Geological Survey, County Atlas Series C-13, Part B, Plate 8.

Berg, J.A. 2004b. Sensitivity to pollution of the uppermost bedrock aquifers: Minnesota Geological Survey, County Atlas Series C-13, Part B, Plate 10.

Boerboom, T.J. (2001) Bedrock geological map and sections: Minnesota Geological Survey County Atlas Series C-13, Part A, Plate 2.

Boerboom, T.J., Runkel, A.C. and V.W. Chandler (2002) Bedrock geology of Pine County, Minnesota: In: T.J. Boerboom (Project Manager), Contributions to the geology of Pine County, Minnesota, Minnesota Geological Survey Report of Investigations 60, pp. 1-20.

$\mathrm{E}^{\mathrm{x}}$ ponent (2004) Hydrogeologic Investigation of Karst near Askov Lagoon, Askov, Minnesota, Report to the Minnesota Pollution Control agency, 20 p. +18 figures +10 tables, +3 appendices.

Jannik, Nancy O., Alexander, E.C. Jr. and Landherr, Lawrence J. (1992). The Sinkhole Collapse of the Lewiston, MN Waste Water Treatment Facility Lagoon. In: Quinlan, J. and Stanley, A., (editors) Proceedings of 3rd Conference on Hydrogeology, Ecology, Monitoring of Ground Water in Karst Terranes. Nashville, TN, Dec. 4-6, 1991. NGWA, Dublin, Ohio, p. 715-724.

Jennings, J.N. (1971) Karst: An introduction to systematic geomorphology, volume seven. The MIT Press, Cambridge, MA.

Jennings, J.N. 1983. Sandstone pseudokarst or karst. In: R.W. Young and G.C. Nanson (Eds.), Aspects of Australian Sandstone Landscapes. Australian and New Zealand Geomorphology Group, Special Publication 1, University of Wollagong, pp. 21-20.

Klimochouk, A., and D. Ford. 2000. Type of karst and evolution of hydrogeologic settings. In: Klimochouk, Ford, Palmer, and Dreybrodt (Eds.), Speleogenesis: Evolution of Karst Aquifers. National Speleological Society, Alabama, pp. 45-53.

Ojakangas, R.W., Morey, G.B. and Green, J.C. (2001) The Mesoproterozoic midcontinent rift system, Lake Superior region, USA. Sedimentary Geol. 421-442.

Patterson, C.J., and Knaeble, A.R. (2002) History of glaciation in Pine County, Minnesota. In: T.J. Boerboom (Project Manager), Contributions to the geology of Pine County, Minnesota, Minnesota Geological Survey Report of Investigations 60, pp. 21-41.

Shade, Beverly L. (2002) The Genesis and Hydrogeology of a Sandstone Karst in Pine County, Minnesota, University of Minnesota Masters Thesis, $171 \mathrm{p}$.

Shade, B.L., Alexander, E.C. Jr., Alexander, S.C. and Martin, S. (2001) Plate 6 - Sinkhole Distribution, County Atlas Series, Atlas C-13, Part A, Minnesota Geological Survey, St. Paul, Minnesota.

Shade, B.L., Alexander, S.C. and Alexander, E.C. Jr. (2002) Karst features in Pine County, Minnesota. In: T.J. Boerboom (Project Manager), Contributions to the geology of Pine County, Minnesota, Minnesota Geological Survey Report of Investigations 60, pp. 55-91.

Truong, H.T. (2000) Sinkhole formation and mapping in Banning State Park, Pine County, Minnesota. Abstract, $14^{\text {th }}$ National Conference on Undergraduate Research, April 27-29, 2000, Missoula, Montana, Abstract Book, p. 211.

Wray, R.A.L. (1997) A global review of solutional weathering forms on quartz sandstones. Earth-Science Reviews, v. 42, pp. 137-160. 